\title{
Did Discount Rate Changes Affect the Foreign Exchange Value of the Dollar During 1978?
}

\author{
DOUGLAS R. MUDD
}

S. monetary policy in 1978 showed an increased sensitivity to international considerations, as indicated by statements accompanying last year's discount rate changes (see Exhibit I). Conditions in foreign exchange markets were cited among the reasons for five of the seven discount rate increases in 1978. In contrast, international considerations were not mentioned among the reasons for any of the four discount rate changes in the previous two years. ${ }^{1}$

Some economists believe that discount rate increases affect financial asset markets through "announcement effects" which, by causing market participants to expect future interest rates to be higher than previously anticipated, exert immediate downward pressure on financial asset prices. ${ }^{2}$ Several studies have found support for the existence of such announcement effects on the U.S. and Canadian economies, while another has discovered no evidence of a significant relationship between discount rate changes and fuctuations in financial asset prices in the United States over the recent past. ${ }^{3}$

1"Announcements," Federal Reserve Bulletin (January 1976), p. 65; (December 1976), p. 1061; (September 1977), p. 867; (November 1977), p. 1031.

For an extensive discussion of the announcement effect see Warren L. Smith, "The Instruments of General Monetary Control," National Banking Review (September 1963), pp. 47-76.

aEvidence of announcement effects on common stock prices in the United States was presented by Roger N. Waud, "Public Interpretation of Federal Reserve Discount Rate Changes: Evidence on the "Amouncement Effect," Econometrica (March 1970), pp. 231-50. Evidence of announcement effects on the Canadian economy was presented by M. L. Kliman, "The Administered Bank Rate and Its Announcement Effect," Canadian Journal of Economics (November 1974), pp. 62541. For evidence against the existence of any sort of meaningful announcement effects in the United States after 1967 see Raymond E. Lombra and Raymond G. Torto, "Discount Rate Changes and Announcement Effects," Qtarterly Journal of Economics (February 1977), pp. 172-76.
This article examines, in a relatively non-technical fashion, the announcement effect of discount rate changes on the foreign exchange value of the dollar in 1978. Despite the reported purposes of these discount rate increases, there does not appear to have been a general, significant announcement effect of discount rate changes on foreign exchange markets.

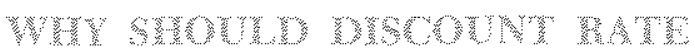

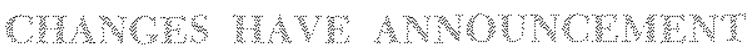 Whaters?}

The discount rate is the interest rate charged by the Federal Reserve on short-term loans to member banks. Under present operating procedures, the effectiveness of discount rate changes per se in achieving the general objectives of monetary policy, particularly the control of bank reserve or money stock growth, is questionable. Increases in reserve requirements and Federal Reserve sales of U.S. Government securities reduce the amount of member bank reserves available to expand loans and deposits. Discount rate increases, however, do not necessarily produce the same effect. Although increases in the discount rate raise the cost of borrowing reserves, borrowings from the Federal Reserve comprise a minor proportion of total reserves. ${ }^{4}$ Raising the discount rate to reduce member bank borrowing is neither a powerful nor a widely-used monetary policy tool at the present time.

\footnotetext{
4See R. Alton Gilbert, "Benefits of Borrowing from the Federal Reserve when the Discount Rate is Below Market Interest Rates," this Review (March 1979), pp. 25-32 and Elijah Brewer, "Some lnsights on Member Bank Borrowing," Federal Reserve Bank of Chicago Economic Perspectives (November/ December 1978), pp. 16-21.
} 


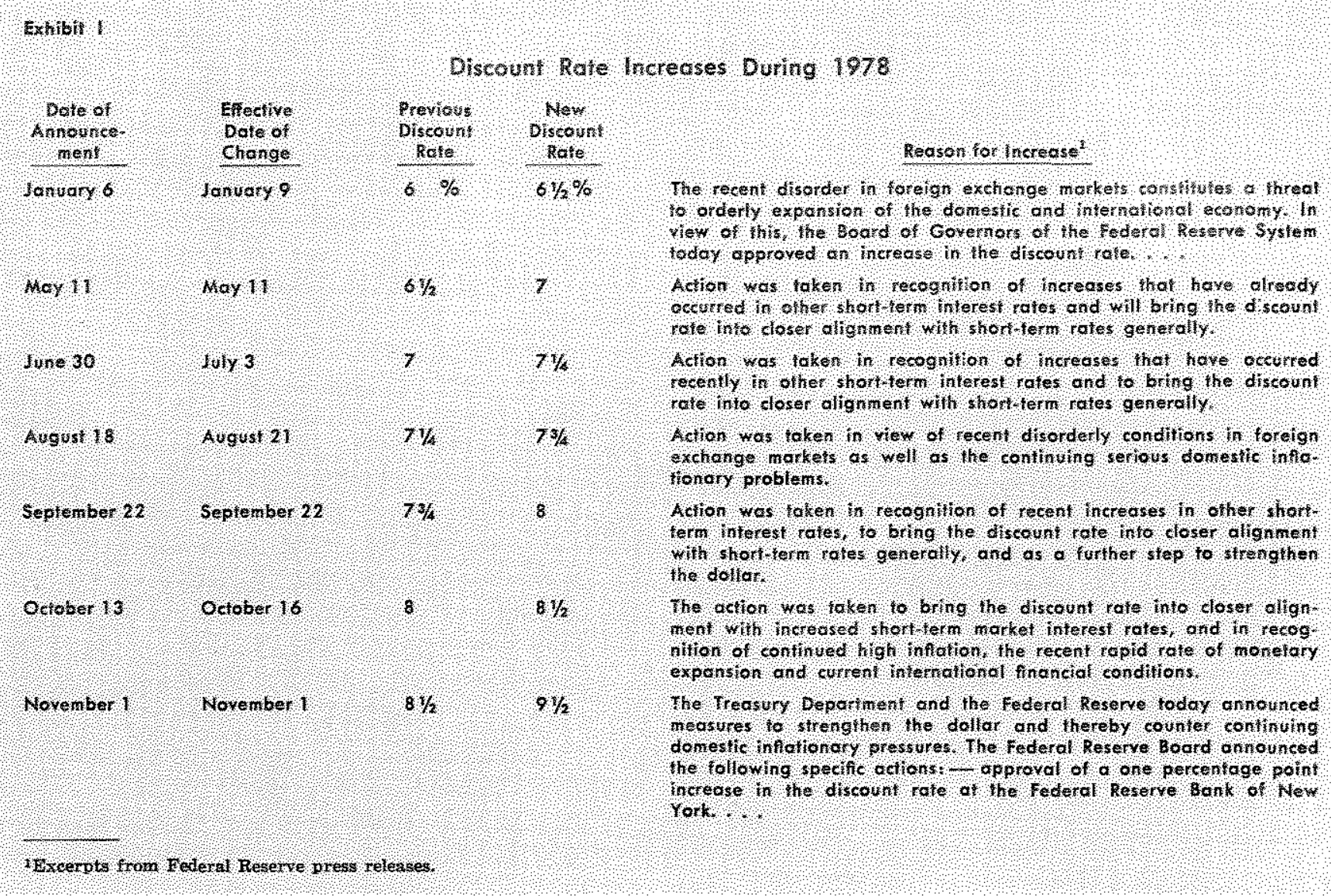

Nevertheless, announcements of discount rate changes may affect economic activity if they seem to signal unanticipated changes in future monetary policy, since such changes in expectations generally are presumed to influence trading in equity and finan" cial asset markets, such as the markets for bonds, common stocks, and foreign currencies. For example, stock prices might fall subsequent to an announcement of a discount rate increase if it seemed to signal an unanticipated change in policy toward monetary restraint. Expected future sales and, hence, profits of firms would fall as expected future growth in aggregate demand is revised downward, resulting in a current drop in equity prices.

Similarly, foreign exchange market participants could also interpret a discount rate increase as an indication of unanticipated future U.S. monetary restraint. If expectations about U.S. money stock growth were fundamentally related to the foreign exchange value of the dollar, changing expectations of future money growth would have an immediate impact on the relaw tive prices of currencies on the foreign exchange market. Announcements of unanticipated changes in U.S. monetary policy thus would result in immediate

changes in the foreign exchange value of the dollar. For example, if U.S. money stock growth were previously expected to remain high but now is expected to decline significantly, an upward adjustment in the foreign exchange value of the dollar should result.

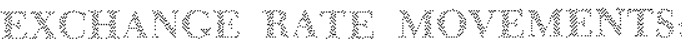 A MOMP}

The effects of changes in expectations of future monetary actions on the foreign exchange value of the dollar should be analyzed within a monetary framework in which exchange rates are identified as the relative prices of national moneys. 5 The "price" of a national money is measured by the amount of goods, services, and financial assets which can be purchased for a unit of that money. If the outstanding stock of money is larger than the amount people desire to hold (given current levels of real income, interest rates, and prices), the attempt to reduce

5ee Michael Mussa, "The Exchange Rate, the Balance of Payments and Monetary and Fiscal Policy Under a Regime of Controlled Floating," Scandinavian Journal of Economics, No. 2 (1976), pp. 229-48, especially pp. $230-36$. 
money holdings by increasing purchases of goods, services, and financial assets will result in a general increase in their prices. Consequently, the amount of goods and services (including financial assets) which can be purchased for a unit of money declines; the price of money falls.

Similarly, the exchange value of one currency in terms of another will fall if the price of one currency in terms of goods and services falls relative to the price of the other currency. Consider the following hypothetical example: Suppose that, at current general price levels in both Germany and the United States, the dollar/mark exchange rate is one to one, and that the amount of goods and services which can be purchased in the United States for one dollar equals the amount which can be purchased in Germany for one mark. Now, let U.S. prices unexpectedly rise by, say 10 percent, while German prices remain constant. The amount of goods and services which one dollar can purchase in the United States is now 10 percent lower than the amount which can be purchased for one mark in Germany. At the existing exchange rate, people will now prefer to convert dollars to marks and purchase the relatively cheaper German goods and services. Subsequent purchases of marks with dollars will result in a 10 percent rise in the price of the mark in terms of dollars - or conversely, a 10 percent fall in the price of the dollar in terms of marks - provided that no attempt is made to "peg" the exchange rate. ${ }^{b}$

It should be clear that the dollar/mark exchange rate represents the U.S. dollar price of one German mark. At any point in time, this price will be determined by the relative amounts of U.S. and German moneys in existence and the relative amounts of each currency which people are willing to hold. A simplified algebraic representation of the exchange rate determination is:

$$
e=\left(\frac{M_{u s}}{M_{r}}\right)\left(\frac{L_{r}}{L_{u s}}\right)
$$

or, in terms of growth rates:

$$
\dot{\mathrm{e}}=\left(\dot{\mathrm{M}}_{\mathrm{w} w}-\dot{\mathrm{L}}_{\mathrm{u} x}\right)-\left(\dot{\mathrm{M}}_{\mathrm{f}}-\dot{\mathrm{L}}_{\mathrm{f}}\right)
$$

where $e$ is the price of a unit of foreign currency in terms of the U.S. dollar, $M_{\mathrm{us}}$ is the U.S. money stock, $\mathrm{M}_{\mathrm{r}}$ is the foreign money stock, $\mathrm{L}_{\mathrm{rus}}$ is the amount of real U.S. money balances people are willing to hold (the demand for real U.S. money balances), $L_{l}$ is the amount of real foreign money balances people are

6This example implicitly assumes that output does not increase proportionally with money stock increases. Further, transportation and other transactions costs are ignored. willing to hold (the demand for real foreign money balances), and " $"$ " is the percentage change.

From the above equations, it is clear that the price of a foreign currency in terms of the U.S. dollar will rise (that is, the dollar will depreciate) if the difference between changes in the U.S. money stock and the demand for U.S. real money balances is greater than the difference between changes in the foreign money stock and the demand for foreign real money balances. It is also clear that relative changes in money stocks alone will determine exchange rate movements only if changes in the quantities of U.S. and foreign moneys demanded are identical $\left(\dot{L}_{\mathrm{as}}=\dot{\mathrm{L}}_{\mathrm{f}}\right)$. There is no reason, however, to expect changes in the quantities of real money balances demanded to be equal across all countries. Thus, relative changes in the amount of moneys demanded are as important as relative changes in money stocks in determining exchange rate movements.

Among the determinants of the demand for real money balances is the expected rate of inflation. An increase in the expected rate of inflation will reduce the quantity of real money balances demanded. Thus, changes in expected rates of inflation among various countries will affect exchange rates through their impact on the amount of national real money balances demanded. A rise in the expected rate of U.S. inflation, all other things remaining constant, will result in a depreciation of the dollar (e rises) by reducing the amount of U.S. real money balances demanded relative to the amount of foreign real money balances demanded ( $L_{\mathrm{u} s}$ declines relative to $L_{p}$ ). The impact on the foreign exchange value of the dollar is reinforced if the change in inflationary expectations results from a rapid increase in the U.S. money stock (in this case, $M_{u s}$ would rise relative to $M_{f}$ and $L_{u s}$ would fall relative to $L_{t}$ ).

Relative amounts of real money balances demanded also can be significantly affected by expectations of future exchange rate movements between two national currencies, another determinant of the demand for real money balances. ${ }^{8}$ That is, all other things being equal, if the expected future foreign exchange

\footnotetext{
${ }^{7} \mathrm{~A}$ formal derivation and discussion of a extended version of this equation can be found in Rudiger Dombusch, "The Theory of Flexible Exchange Rate Regimes and Macroeconomic Policy," Scanditavian Journal of Economics, No. 2 (1976), pp. 255-75.

"See Mussa, "The Exchange Rate," pp, 236-37. Since the expected retum on holdings of foreign rather than domestic currency depends on the expected future exchange rate, factors inthencing expectations of future exchange rates will affect the relative amounts of national moneys demanded.
} 


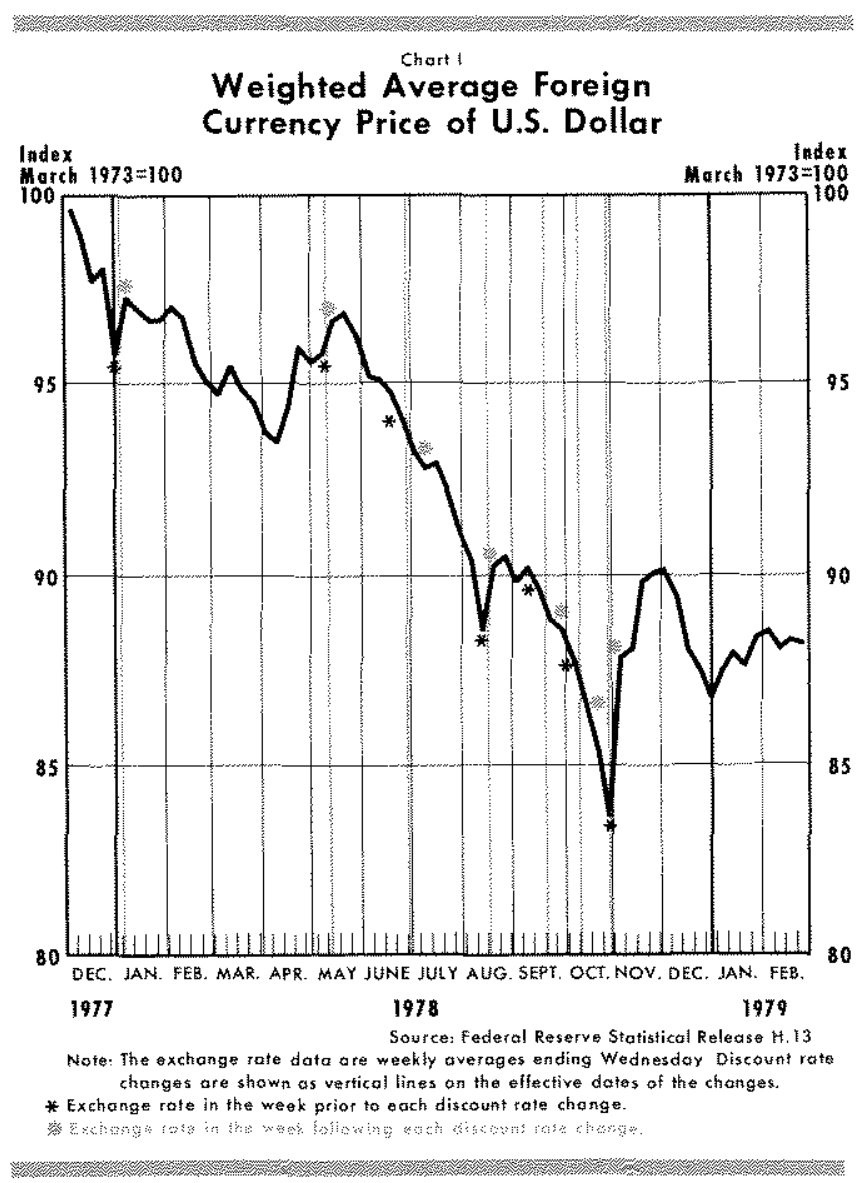

value of the dollar suddenly is revised downward, the quantity of U.S. real money balances demanded could decrease sufficiently relative to the quantity of foreign real money balances demanded to produce an immediate depreciation of the dollar. It is assumed that expectations of future exchange rates are formed primarily on the basis of expectations about the future value of variables which determine the amounts of national moneys demanded and supplied. Thus, changing expectations of future relative money stock growth rates (and, hence, relative levels of various future national money stocks) will produce fluctuations in current exchange rates.

If discount rate increases are interpreted as indications of unanticipated future U.S. monetary restraint, expectations of future U.S. money stock growth (and, hence, future U.S. inflation rates) would be lowered, resulting in a rise in the expected future foreign exchange value of the dollar. The quantity of dollars currently demanded would then rise relative to the quantities of other currencies demanded, perhaps sufficiently enough to result in a rise in the current foreign exchange value of the dollar, even if U.S. money stock growth does not immediately decelerate.
However, if no indication of actual monetary restraint subsequently appears, the rise in the value of the dollar would be reversed.

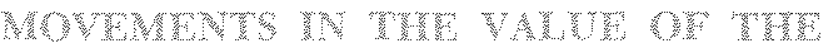

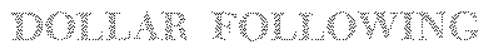

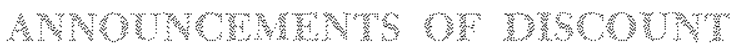

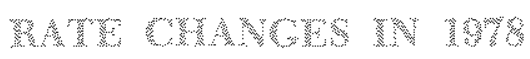

To what extent did last year's discount rate increases affect the foreign exchange value of the dollar? Of the seven announcements accompanying the discount rate increases in 1978 , only those of May 11 and June 30 did not mention foreign exchange market conditions. The other five listed "disorderly" foreign exchange market conditions among the reasons for the discount rate change. The data presented in Chart I provide little indication that the stated purposes for raising the discount rate had a subsequent influence on the behavior of the dollar on foreign exchange markets.

The May 11 discount rate increase was preceded by several weeks of generally stable dollar exchange rates, and was followed by two weeks of only a slight increase in the foreign exchange value of the dollar. In contrast, the July 3 change in the discount rate was preceded by a period of generally declining dollar exchange rates, which continued until midAugust. Thus, there appears to be no obvious. change in the direction of exchange rate movements following those announcements which ignored foreign exchange market conditions.

There also was little change in the generally declining pattern of the weekly-average foreign exchange value of the dollar following the September 22 and October 16 discount rate increases, although international financial conditions were listed among several reasons for these increases. The value of the dollar on foreign exchange markets did rise following the discount rate increases of January 9 , August 21, and November 1. The announcements of these changes dealt almost exclusively with foreign exchange market conditions.

An examination of the weekly percentage changes in the average foreign exchange value of the dollar for the weeks surrounding each discount rate increase in 1978, shown in Table I, apparently denies the existence of a general announcement effect. First, three of the seven $D_{1}$ differences in one-week changes are inconsistent with the announcement effect hypoth- 
esis. The value of the dollar actually fell more during the week of the discount rate increases of July 3, September 22, and October 16, than it had in the week preceding each of these changes. Further, considering all seven cases together, one cannot reject the hypothesis that the percentage change in the foreign exchange value of the dollar in the week of each discount rate increase did not differ significantly from the change in the prior week. $^{9}$

Similarly, one cannot reject the hypothesis that the percentage change in the foreign exchange value of the dollar in the week following each discount rate change did not differ significantly from the change in the week before each rate increase. ${ }^{10}$ In other words, a simple statistical test on the differences in Table I indicates that, in general, there was no major impact on the foreign exchange value of the dollar consequent to the discount rate increases in 1978.

This conclusion can be tested more rigorously, using a simple statistical model of the weekly percentage changes in the foreign exchange value of the dollar. The model is autoregressive. This means that in the absence of discount rate changes, the weekly percentage change in the foreign exchange value of the dollar depends upon a constant (called "drift") and the change over the prior week. This model allows past information on exchange rate movements to affect the current week's change. ${ }^{11}$

Announcement effects can be tested by examining the impact of discount rate changes on changes in the foreign exchange value of the dollar over several weeks following each discount rate change. To examine this impact, weekly percentage changes in the

\footnotetext{
9Testing the significance of the difference between the sample mean of $D_{1}$ from a hypothetical value of zero yields a $t$ statistic of 0.72 .

10Testing the significance of the difference between the sample mean of $\mathrm{D}_{2}$ from a hypothetical value of zero yields a tstatistic of 1.74 .

11 Ir an efficient market, knowledge of the past change in the exchange rate should provide no useful information about the change in the exchange rate in the current week. Under this hypothesis, weekly percentage changes in the exchange rate are referred to as a "Fandom walk" (with or without "drift," depending upon the significance of the constant).
}

weighted average foreign exchange value of the dollar were regressed against a constant, the percentage change in the foreign exchange value of the dollar in the previous week, and dummy variables designed to represent the one-, two-, and three-week announcement effects following the discount rate changes. The results appear in Table II.

If the coefficient on the previous week's percentage change in the exchange rate $\left(\Delta \ln X_{t-1}\right)$ is not significantly different from zero (which is the case in both equations), then changes in the foreign exchange value of the dollar are a function of the constant, the announcement effect of discount rate changes (represented by the dummy variables), and a random error term. The constant is significantly negative in both equations, indicating downward "drift" in the exchange rate of about .3 percent per week during the sample period.

Equation 1 in Table II indicates that the discount rate changes in the period, September 14, 1977February 14, 1979, did have a significant one-week impact on the value of the dollar on foreign exchange markets. However, this result can be further analyzed in light of the importance of unanticipated discount rate changes in the formulation of the announcement effect hypothesis. 
Table II

Estimation of Amnouncement Effects

September 14,1977 - February 14,1979

Equation 1 :

$\Delta \ln X_{t}=a_{1}+a_{1} \Delta \ln X_{t}+a_{2} D_{3}+a_{3} D_{2}+a_{4} D_{3}$
$a_{1}=0.0037^{\circ}$
$a_{2}+0.0151 \%$
$\overline{\mathrm{R}}^{\mathrm{s}}-0855$
$\mathrm{a}_{1} \rightarrow 0.1203$
$a_{3}-0.0050$
$\mathrm{DW}=20464$
a $=0.0052$
$\mathrm{SE}=\mathbf{0 0 9 6}$

Equation 2

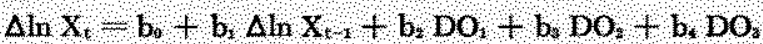

+b, $\mathrm{DN}_{4}+\mathrm{b}, \mathrm{DN}_{*}+\mathrm{b}_{\mathrm{f}} \mathrm{\textrm {DN }}$

$b_{0}=\begin{array}{llll}0.0030^{\circ} & b_{2}= & 0.0050 \\ b_{l}\end{array}$

Aln $\mathrm{X}=$ first difference in logarithms of weighted average foreign cur rency price of US, dollar.

D, $\mathrm{D}_{3}, \mathrm{D}_{3}=$ dumany variables representing the first, second, and third week amouncement effeets subsequent to discount rate ehanges.

$\mathrm{DO}_{1}, \mathrm{DO}_{2}, \mathrm{DO}_{3}$ - durnmy variables representing the first, second, and third week announcenent effeets subsequent to all dis. count rate elanges except the November 1,1978 change.

$\mathrm{DN}_{1}, \mathrm{DN}, \mathrm{DN}_{3}$ - dummy variables representing the first, second, and third week announcement effects subsequent to, the November 1,1978 discount rate change

* Significantly different fron zero at the 95 pereent level

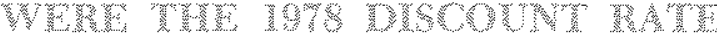

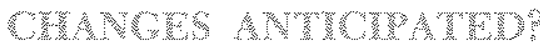

If an announcement of a discount rate change represents "new" information, a change in the behavior of the dollar on foreign exchange markets could result as expectations are revised. If the discount rate change had been previously anticipated, however, it would not alter expectations, and, hence, would have no impact on the foreign exchange value of the dollar. For example, following the discount rate change on August 21 , it was reported that ". . . the Federal Reserve's move to raise the discount rate by half a percent... was so predictable as to be almost insignificant in the view of most traders." ${ }^{\text {"12 }}$

12Wendy Cooper, "Currency Traders Expect New Moves," New York Joutral of Commerce, August 21, 1978.
Anticipation of discount rate changes during 1978 could have resulted from a recognition that they generally follow a wide spread between the discount rate and short-term market interest rates. The spread between the Federal funds rate (the interest rate paid by commercial banks on reserves borrowed from other commercial banks) and the discount rate over the past fifteen months is depicted in Chart II. As shown in the chart, each discount rate change in 1978 was preceded by at least one week during which the spread between the funds rate and the discount rate was 60 or more basis points.

The November 1 discount rate increase, however, differed in several respects from the other six changes. First, it followed the previous change by only fifteen days. The average length of time between the five discount rate changes between May and October was thirtynine days. Second, its one percentage point increase in the discount rate was the largest increase since March 1933. Third. it accompanied statements about the U.S. Treasury and Federal Reserve System's intentions of intervening in foreign exchange markets to support the dollar. ${ }^{13}$ Consequently, the November 1. announcement could have had a larger impact on expectations of future U.S. policy actions affecting the foreign exchange value of the dollar than the previous six announcements in 1978.

Whether the November 1 announcement produced a significantly greater impact on foreign exchange market participants' expectations than the previous discount rate changes can be determined by comparing the estimation results of equations 1 and 2 in Table II. Changes in the foreign exchange value of the dollar following the November 1 announcement were accounted for by a separate set of dummy vari-

\footnotetext{
13The November 1 announcement included the following measures intended to strengt?en the dollar: (1) a one percentage point increase in the discount rate; (2) a supplementary reserve requirement equal to 2 percent of time deposits in denominations of $\$ 100,000$ or more; (3) the arrangement of various farilfties through which the United States could obtain un to $\$ 30$ billion in foreign emrencies to be used in foreign exchange market intervention to support the dollar and (4) a guadrupling of previously announced U.S. Treasuy gold sales (to 1.5 billion ounces per month).
} 


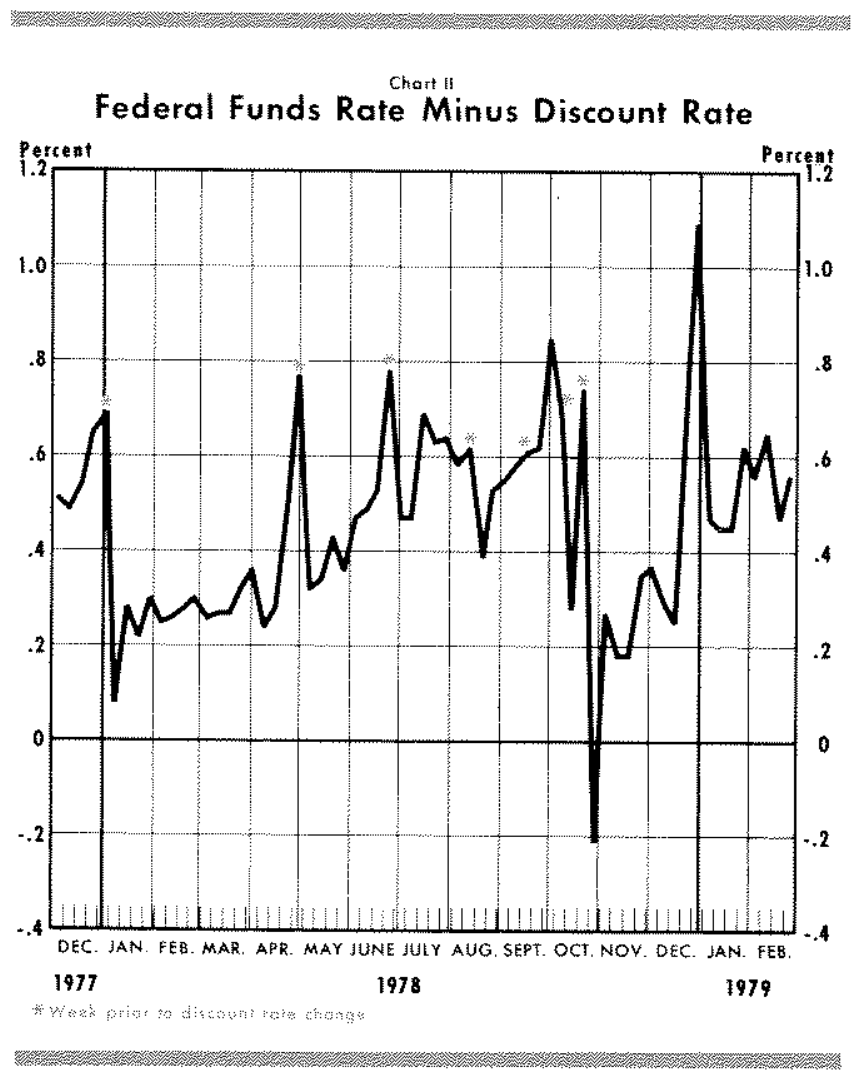

ables in equation 2 . The results indicate that percentage changes in the foreign exchange value of the dollar for three weeks following the November 1 discount rate change increased significantly. However, on average, the discount rate changes prior to November 1 had no significant effect on changes in the foreign exchange value of the dollar (none of the individual coefficients on the dummy variables, nor their sum, is significantly different from zero at the 95 percent level). Furthermore, since the November 1 announcement contained information other than a discount rate increase which could have affected expectations about U.S. policy actions, evidence for a November 1 announcement effect could be overstated by equation 2 .

There are indications that the January 9 discount rate increase also significantly affected the value of the dollar on foreign exchange markets. For example, despite the 69 basis point spread between the Federal funds rate and the discount rate in the week before the change, several sources described the January 9 discount rate increase as unanticipated. ${ }^{14}$ More importantly, however, the discount rate increase

${ }^{14}$ See, for example, J. Henry Schroder Bank \& Trust Company, "The Schroder Report", January $16,1978, \mathrm{p} .1$ and Aubrey G. Lanston \& Co. Inc, January 16, 1978 , p. 1. followed (by only two trading days) the announcement that the U.S. Treasury and Federal Reserve would actively use the "swap" network to "... reestablish order in the foreign exchange market."15 Again, this announcement could have had a larger impact on foreign exchange markets than the subsequent increase in the discount rate ${ }^{16}$ However, when viewed more generally (as in Table II, equation 2), any announcement effect which might be attributed to the January 9 discount rate increase does not alter the conclusion that the foreign exchange value of the dollar was, in general, unaffected by the six discount rate increases between January and October 1978.

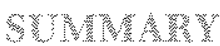

According to a monetary interpretation, relative changes in the differences between the amounts of money supplied and demanded across countries are the primary determinants of exchange rate movements. If changes in expectations cause exchange rate fuctuations, then variations in expected future money stock growth rates could produce such fuctuations. For example, if the growth of the U.S. money stock suddenly is expected to decline, a short-term appreciation of the dollar could result as the amount of U.S. money demanded rises relative to the amount of foreign money demanded (assuming nothing else changes at the same time).

The seven announcements of U.S. discount rate increases during 1978 could have been interpreted as signals of forthcoming monetary restraint. A temporary reversal in the declining pattern of the foreign exchange value of the dollar followed the three announcements which focused primarily on strengthening the dollar as a reason for increasing the discount rate. However, there is evidence that, except for the November 1 change, the foreign exchange value of the dollar was not generally influenced by the discount rate increases announced last year.

15Federal Reserve, press release, January 4, 1978. A "swap" arrangement is a renewable short-term facility under which a central bank agrees to exchange a specified amount of its own currency for the currencies of other central banks.

16 The results of estimating an equation simitar to equation 2 in Table II with separate dummy variables for the Jantary discount rate increase indicate a significant coefficient on the dummy variable representing the annomcement effect in the week following the discount rate change. However, in both the November and January cases it is not possible from these results to separate any announcement effects of the discount rate changes from any effects associated with statements about the United States' intentions to support the value of the dollar through foreign exchange market intervention. 